\title{
Owner-Manager Competencies and Performance of the Firms: Evidence from Small Restaurant Businesses in Urban Tanzania
}

\section{Ruth Elias ${ }^{1}$ Joshua Mwakujonga ${ }^{2}$ (iD}

${ }^{\prime}$ Collage of Business Studies and Law, University of Dodoma, Dodoma, Tanzania Emaileliasruth75@gmail.comTel:+255715220087

'Department of Business Studies, Mzumbe University, Dar es salaam Campus Collage, Tanzania. Emailmjoshua@mzumbe.ac.tzTel: +255685860656

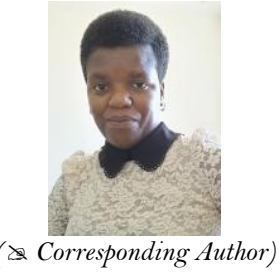

( Corresponding Author)

Abstract

This study was set out to examine the influence of owner- manager's competences on the performance of small restaurant businesses in urban Tanzania since there are patchy empirical evidences on the same. To achieve this, criterion and simple random sampling techniques were employed to obtain a sample of three hundred, ninety two (392) small restaurant businesses from the list of all licensed small restaurants in Ilala and Dodoma district. Information was collected from owner-managers of these entities by using structured questionnaires. Data was analyzed both descriptively and by using structural equation modelling for making inference. Confirmatory Factor Analysis was performed to validate the items measuring the owner-manager entrepreneurial, managerial and functional competencies as latent variables. Performance of small restaurant was measured subjectively by considering the number of customer's dynamics and changes in lifestyle of the owner-manager as a result of the business undertaken over past three years of operation. It was found that owner-manager's managerial and functional competencies contribute significantly to the performance of the small restaurant businesses in urban Tanzania. This is true but they cannot be in operation unless entrepreneurial competencies are in place. This implies that, performance relies on base (entrepreneurial) and operational (managerial and functional) that need to be improved. As such, policy makers may not only rely on entrepreneurial aspects but also extend to the managerial and functional aspects of performance.

Keywords: Owner-manager, Entrepreneurial, Managerial, functional, competencies, Performance, Small restaurant businesses. JEL Classification: M 5, M 10

Citation | Ruth Elias; Joshua Mwakujonga (2019). Owner-Manager Competencies and Performance of the Firms: Evidence from Small Restaurant Businesses in Urban Tanzania. Asian Journal of Economics and Empirical Research, 6(2): 140-147. History:

Received: 6 August 2019

Revised: 10 September 2019

Accepted: 14 October 2019

Accepted: 14 October 2019

Licensed: This work is licensed under a Creative Commons Attribution 3.0 License (cc)

Publisher: Asian Online Journal Publishing Group
Acknowledgement: Both authors contributed to the conception and design of the study.

Funding: This study received no specific financial support.

Competing Interests: The authors declare that they have no conflict of interests.

Transparency: The authors confirm that the manuscript is an honest, accurate, and transparent account of the study was reported; that no vital features of the study have been omitted; and that any discrepancies from the study as planned have been explained.

study as planned have been explained.
Ethical: This study follows all ethical practices during writing.

\section{Contents}

1. Introduction

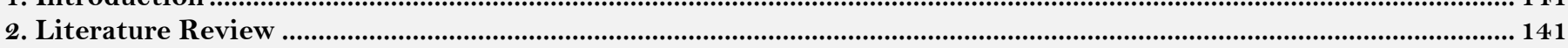

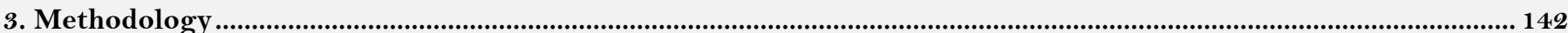

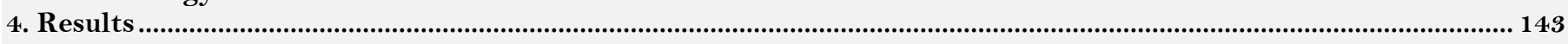

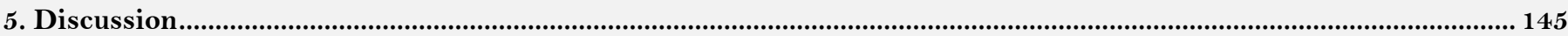

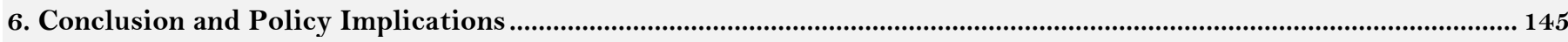

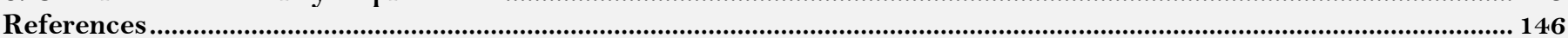




\section{Contribution of this paper to the literature}

This study contributes to the body of literature that, the three competencies complement each other in the performance of small restaurant business. The managerial and functional competencies play great roles in the performance of small restaurant business. However, they cannot be in operation unless entrepreneurial competencies come first. Entrepreneurial competencies are static in nature because they explore the prevailing opportunities of the business and set operational needs of the business on which managerial and functional is attached to ensure the performance. On the other way, entrepreneurial competencies may be important in explaining performance to other sector, nature, size, or competition of the business. Unless it is measured in different size, nature, sector and competition of the business we may not know if they can improve performance.

\section{Introduction}

The performance of restaurant industry has captured the awareness of researchers due to their overall contributions to the country's economy (Jenkins, 2015; Jogaratnam, 2017). Literature shows that the industry is the second largest employers in many countries as it builds labour opportunities for skilled and unskilled individuals given a range of business capital in their operation (Khan, 2010; Frazer, 2012; Jenkins, 2015). In Tanzania specifically, the hospitality sector contributes 5.5 per cent of national gross domestic product (GDP) (MIGA, 2002). Estimates suggested that small hotels and restaurants add over 70 per cent of these contributions (Sharma and Upneja, 2005). In additional the sector brings greater economic benefit in providing employment opportunity (Nangale, 2012).

Despite its economic benefit to the society, it has been documented that small restaurant businesses tend to lose customers as compared to other food related service providers like food vendors, take away food service providers, pubs, bars, and catering services (Parsa et al., 2011). As a result, small restaurant businesses performance and their survival remain questionable (Parsa et al., 2011). Statistical evidences shows that, statistical evidence show that, $60 \%$ of the small restaurants businesses collapse within three years of their operation (Frazer, 2012) in which small restaurant business in Tanzania is of no exception.

On the other hand, it is reported that in order to operate a small restaurant business in Tanzania urban areas, municipal/urban laws and regulation requires one to own or rent a premise with good design, sanitation system and storage facilities in an appropriate location for their safety and efficiency. Despite the good intention of the laws, regulations and design procedures for the small restaurant businesses, practically they impose challenges to the restaurant business owners. As a result, owner-managers seem to be unable to comply for such requirements due to their capital margins. In addition, these small restaurant businesses operates in a competitive environment with rapid changes in customer tastes and preferences (Dirisu et al., 2013). Therefore, under the given business environment, the author is of the view that, competencies of the owner-manager might be the necessary input for the performance of the small restaurant businesses. This is because large proportion of the difference in performance among small restaurant businesses can be explained by the individual who own and operates the businesses (Frazer, 2012; Sabir et al., 2014; Jenkins, 2015).

Academic literature shows scant evidence on the effect of owner-manager competencies to the performance of small restaurant businesses against the larger business (Anyim et al., 2012). Besides the findings from the studies on individual competencies revealed from large businesses cannot be generalized to all businesses as they are relative and specific to the size/scale and sector of the business. However, competencies to the performance of the large business are absolutely complimented with many people, discipline and department from which small business sector is deprived of as it is managed by individuals. Thus, applicability and generalization of their findings are questionable based on the nature of small restaurant businesses as they differ in ownership, number of employees, capital as well as the sector. The focus of this paper therefore is to find out the relationship between owner-manager competencies and performance of small restaurant businesses in urban Tanzania context.

\section{Literature Review}

\subsection{Theoretical and Empirical Review}

Human capital theory shows that an individual with necessary competencies (skills and knowledge) can perform better than those who do not have one (Becker, 1964). In a small business, the owner-manager often approves on the way things are done. Moreover, the owner-manager is the one who is responsible for entrepreneurial, managerial and functional roles of the business (Ahmad et al., 2010). Thus, the success or failure of these businesses depends on owner-manager competencies to perform such roles (Longenecker et al., 1999; Munene et al., 2013).

\subsubsection{Entrepreneurial Competencies}

The modern marketing orientation asserts that to undertake entrepreneurial activities successfully, ownermanager needs different skill/knowledge that relate with the performance of those activities. Pieces of literature have consistently shown different skills and knowledge (competencies) on fulfilling entrepreneurial activities in large business performance (Fatoki, 2013; Tendai, 2013; Mothibi, 2015). However, the applicability of those skills in small business may not be appropriate; rather it gives out the base for the research in small business. Therefore, the reviewed literature shows that; the owner-manager who wishes to make the business successful and build competitive advantage in gaining customers must have the ability to identify and anticipate the needs of their customers (Suchánek et al., 2015) taking problem as opportunity (Man, 2001) sell food and services at low price than competitors (Kaura, 2012; Gagić et al., 2013) and search for future information regarding the restaurant customers (Koutroumanis, 2011). The knowledge helps the owner-manager to provide the product according to the customers' expectations (Gursoy and Swanger, 2007). This will help the business to maintain and attract more customers for business performance. However, these results are limited to large businesses. 


\subsubsection{Managerial Competencies}

For the owner-manager to undertake managerial activities successfully, he/she needs different competencies that are related to the performance of those activities. Researchers have consistently shown different skills and knowledge (competencies) on fulfilling managerial activities for business performance (Fatoki, 2013; Tendai, 2013; Mothibi, 2015). The appropriateness of the managerial competencies that match with the activities undertaken is based on the nature, size, and location of the business, as well as the type of customers, served and quality of employees. For example; literature shows that drivers towards success can be traced on the ability of the manager to lead employees, motivate employees (Anyim et al., 2012) delegate (Eddie, 2002) and create good network with competitors (Tendai, 2013) However, much of knowledge about management of employees has relevance to large organizations and fails to address the distinctive characteristics of the small business. It is thus the work of this study to unpack the experience from small restaurant businesses.

\subsubsection{Functional Competencies}

The owner-manager, who has the overall control of all activities of the firm and especially in the small firm, must undertake functional activities. In which these activities are related to the technical ability of the ownermanager to perform in the business. Masoud (2013) findings showed that there is a significant impact of the functional competencies on the business performance, and explains that (57.6\%) of the variation in business performance are from the low level of technical competencies. Technical Competency is a significant component that owner-managers should possess to perform the jobs associated with the technical field within a firm in an effective way (Mohamad and Sidek, 2013). The technical ability of the owner-manager is necessary for product/service differentiation. There is a consensus among the social scientists that it is crucial for the individual to have the ability of technical know-how in handling the business successfully (Chandler and Hanks, 1994; Bird, 1995; Chu et al., 2005; Chu and Benzing, 2009; Ahmad et al., 2010; Mohamad and Sidek, 2013). Drawing on the concept of functional competencies, factor ranging from appropriate use of modern equipment on food preparation, food preparation skill and the ability to deliver food to customer's places are contributing to the success of restaurant businesses. Likewise, the ability to be visible by customers while preparing food and attractive restaurant environment (Chen and Hsieh, 2011; Mandabach et al., 2011) were also identified as the factor that attracts customers to dine in a certain restaurant. Besides, findings of the studies show different results among researchers.

\section{Methodology}

\subsection{Research Approach and Design}

This study followed the explanatory cross-sectional design because the purpose of the study was to explain the relationship. The study borrowed already identified item measuring competencies from the literature and tests their causal effect relationship with performance on small restaurant business into Tanzania context (Man, 2001). It is also a cross-sectional design because it is a population-based survey. The choice of cross-sectional design was also based on the nature of our research objective as well as on the fact that our unit of analysis (small restaurant businesses) does not keep proper secondary data of their undertakings.

\subsection{Study Population and Sampling}

This study examined the influence of owner-manager competencies on performance of small restaurant businesses by using quantitative method approach. The definition of small business in Tanzania based on SME policy of 2003 is a business with 5 to 49 employees, and with a capital of from 5-200 million (U.R.T., 2003). In the case where a business falls under more than one category, the level of investment is the deciding factor. However, during the pilot study the author found that most of licensed small restaurant businesses had capital of 5-20 million and employ not more than 10 employees. Thus, necessitated the study to take sample with aforementioned criteria. Furthermore, similar characteristics of these small restaurant businesses helped the study to have homogeneity units of analysis to avoid issues of biasness. The study also selected the small restaurant business that has been in operation for at least three 3-10 years during the interview in order to be able to capture the experience of the owner-manager competencies for at least past three years and not more than ten years to avoid biasness of the result as most of them when they reach ten years in business graduate to medium business. Furthermore, the sample size of this study comprised of 392 small restaurant businesses. Sample size was selected through proportional allocation to size within two municipalities in order to have representative sample for generalization.

\subsection{Data Collection Method and Tool}

The main tool of data collection was a structured questionnaire. It was selected because of its ability to cover a large area and quickly gaining some details about one's population of interest within a short period of time. It is also a major tool in survey method. The design of the questionnaire was based on achieving the research objectives. Furthermore, five SMEs experts and five academicians were invited to pre-test the questionnaire for clarity of the questions, suitability to the participants, needed time, and any possible hindrance on getting appropriate information. After correction, then the questionnaire was piloted to 10 owner-managers to test the validity and reliability of each question in capturing the information used.

\subsection{Measurement of Study Variables}

Due to challenges of obtaining financial information in small business, researchers often assess small business performance by general subjective measures that can reflect objective measures (Tundui, 2012). Moreover, the analysis from the previous studies revealed a high level of positive correlation between objective and subjective measures as well as it was suggested that, there is strong reliability of either measure adopted (Zulkiffli, 2014). This implies that the correct use of a subjective measure of performance is valid and reliable. 
The dependent variable is the Performance of firms measured with two variables: change in lifestyle of the owner-manager as a result of the business and change in number of customers respectively as reflected on Table 1.

Table-1. Measurement of study variables.

\begin{tabular}{|c|c|c|}
\hline S No. & Dependent variable: performance & Measurement \\
\hline$\overline{1}$ & Number of Customers & $\begin{array}{l}\text { The categorical variable measured as the trend of number of } \\
\text { customers over the past three years, decreased, decreased } \\
\text { fairly, Stable, fairly Increased and Increased. }\end{array}$ \\
\hline \multirow[t]{4}{*}{2} & $\begin{array}{l}\text { Changes in lifestyle of the owner- } \\
\text { manager in terms of: }\end{array}$ & Categorical variable measured by three items \\
\hline & $\begin{array}{l}\text { The food that bought on a daily basis has } \\
\text { changed }\end{array}$ & $\begin{array}{l}\text { The categorical variable measured as the changes in food of } \\
\text { the owner-manager as a result of business operations over the } \\
\text { past three years, as a lot less, less, stayed the same, more, a } \\
\text { lot more. }\end{array}$ \\
\hline & $\begin{array}{l}\text { The health care services purchased has } \\
\text { changed }\end{array}$ & $\begin{array}{l}\text { The categorical variable measured as the changes in health } \\
\text { care of the owner-manager as a result of business operations } \\
\text { over the past three years, as a lot less, less, stayed the same, } \\
\text { more, a lot more. }\end{array}$ \\
\hline & The shelter has changed & $\begin{array}{l}\text { The categorical variable measured as the changes in the } \\
\text { shelter of the owner-manager as a result of business } \\
\text { operations over the past three years, as a lot less, less, stayed } \\
\text { the same, more, a lot more. }\end{array}$ \\
\hline
\end{tabular}

Source: Developed from literature review, 2018.

The Independent Variable includes owner-manager entrepreneurial, managerial and functional competencies measured by number of statements representing skills and knowledge of individual for the betterment of the performance. Owner-manager competency measures have been adopted from Man (2001) and grouped as proposed by Ahmad et al. (2011) basing on the three main responsibilities of an owner-manager in the business. On measuring it was required for the owner-manager to indicate their level of agreement on being able to undertake the described entrepreneurial, managerial and functional skills/knowledge based on the item specified in each category. Five scales were used for this purpose: strongly disagree, disagree, neither agree nor disagree, agree, strongly agree. For that way, they were indicating the competency they have for performing prescribed activities.

\subsection{Quantitative Data Analysis}

The quantitative data collected were summarized, coded and analysed using statistical package for social sciences (SPSS) computer programme version 21 and STATA 15. Data analysis was started by descriptive statistics which was used to explain the essential features of the demographic characteristics of the owner-manager and the characteristics of the business surveyed. Structural equational model (SEM) was used in analysing the influence of owner-manager competencies on performance of small restaurant businesses because it is very powerful, convenient and flexible tool used in predicting the relationship between latent and observed constructs. SEM is the second generation of the statistical analytical tool that combines the assessment of the measurement model (confirmatory factor analysis) and structural model estimation (Hair et al., 2006). Confirmatory Factor Analysis (CFA) is the process of validating latent constructs which was done before modelling their interrelationship in SEM. To archive the CFA, we assessed the unidemintionality, construct validity, convergent validity and discriminant validity of the latent constructs as indicated on section 4.2 of the analysis. On the other hand, structural model shows the structural relation on how constructs are related to other constructs. It is the structural section of the model which specifies the hypothesized relationships among variables of the study. Specifically, it had undergone structural relation of owner-manager competencies and performance of the business. The coefficients generated to describe the strength of this relationship are interpreted in much the same way as regression weights.

\section{Results}

\subsection{Descriptive Results}

The aim of this research was to determine the influence of owner-manager competencies on the performance of the small restaurant businesses in urban Tanzania. Prior to inferential analysis, descriptive statistics were considered to make an initial analysis as supporting evidence on the results from the model.

The descriptive statistics results shown in Table 2 indicate that; performance of the restaurant business is a function of owner-manager's competence which is contributed by level of education, marital status and age of the business (Elias et al., 2018). The results show that $86 \%(\mathrm{n}=337)$ of sampled owner-managers with primary and secondary education level probably be affected by deprived skill/knowledge of which contemporary is presumed to be acquired from college and university levels. Though most of them have limited knowledge and skills, 69.4\% $(\mathrm{n}=272)$ of sampled owner-managers were married, their family and marriage experience seem to compliment skills to the performance of the restaurant businesses. In addition, the descriptive statistics show that $24 \%(n=94)$ of the enterprises interviewed had more than six (6) years of operation. Thus, experiences and challenges endured during the life time of the restaurant business seem to enhance competence of owner-managers but in this case they were few hence most of restaurant businesses fail to operate within early years of operation (Frazer, 2012; Jenkins, 2015). The descriptive statistics imply that level of education; marital status and age of the business form the competence of owner managers to performance and sustainability of the small restaurant business. 
Table-2. Descriptive statistics.

\begin{tabular}{l|l|c|c}
\hline No & Variable & Number of owner-managers(n) & Percentage (\%) \\
\hline 1 & Formal Education of the owner-manager & $(\mathrm{n})$ & \\
\hline & Collage/ University education & 55 & 14 \\
\hline & Secondary education & 211 & 54 \\
\hline & Primary education & 126 & 32 \\
\hline & Total & 392 & 100 \\
\hline 2 & Marital status of the owner-manager & $(\mathrm{n})$ & 69.4 \\
\hline & Married & 272 & 22.9 \\
\hline & Single & 90 & 7.7 \\
\hline & Divorced/widow & 30 & 100 \\
\hline & Total & 392 & \\
\hline 3 & Sex of the owner-manager & & 59.9 \\
\hline & Male & 235 & 40.1 \\
\hline & Female & 157 & 100 \\
\hline & Total & 392 & \\
\hline 4 & Age of the business & & 76 \\
\hline & 6 -Mar & 298 & 24 \\
\hline & 10-Jul & 94 & 100 \\
\hline & Total & 392 & 66.3 \\
\hline 5 & No of employees & & 33.7 \\
\hline & $5-J a n$ & 260 & 100 \\
\hline & $10-J u n$ & 132 & 392 \\
\hline
\end{tabular}

Source: Field data, 2018

\subsection{Confirmatory Factor Analysis}

To determine the influence of owner-manager competencies on performance of the firm; we first run confirmatory factor analysis among the owner-manager competencies (entrepreneurial, managerial and functional) construct. Confirmatory factor analysis was meant to test whether the measures of these construct are consistent with the researcher's understanding of the nature of that construction. Likewise, all measurement models must be validated and accepted prior to modeling the structural model. The polled confirmatory factor analysis (borrowed from the study by Elias et al. (2018) was used to validate the competencies (latent construct) which are presents in Table 3.

Table-3. The CFA report for every construct in the model construct.

\begin{tabular}{l|l|c}
\hline Construct & Item & Factor loading \\
\hline Entrepreneurial & Processing food and services that customer wants & 0.93 \\
\hline & Processing food that brings benefit to customers & 0.98 \\
\hline & Sell food at a cheaper price & 0.99 \\
\hline & Take new problem as an opportunity & 0.99 \\
\hline & Assess the trend of small restaurant customers & 0.99 \\
\hline & Prioritize work in alignment with the business goal & 0.99 \\
\hline & Lead employees & 0.98 \\
\hline & Motivate employees & 0.99 \\
\hline & Delegate & 0.94 \\
\hline & Interact with customers & 0.89 \\
\hline & Networking & 0.99 \\
\hline Functional & Use of business support services & 0.96 \\
\hline & Family support & 0.90 \\
\hline & Use modern processing facilities & 0.92 \\
\hline & Use special knowledge in food processing & 0.93 \\
\hline & Offering delivery services & 0.90 \\
\hline & Visibility during processing of food & 0.95 \\
\hline & Design restaurant environment & 0.92 \\
\hline
\end{tabular}

In this study, we had 3 dimensions which are entrepreneurial competencies (6), managerial competencies (7) and functional competencies (5). According to Zainudin (2015) the factor loadings for each item should be 0.6 or higher for an established item. It is apparent from Table 3 that, factor loading are above 0.6. Therefore, confirmatory factor analysis shows that all of the 18 measuring items from three competencies are relevant and were retained for further analysis.

Table-4. The fitness indexes for the polled measurement model.

\begin{tabular}{c|l|l|c|c|c}
\hline S No. & $\begin{array}{l}\text { Name of } \\
\text { category }\end{array}$ & Name by index & $\begin{array}{l}\text { Index } \\
\text { value }\end{array}$ & $\begin{array}{c}\text { Level of } \\
\text { acceptance }\end{array}$ & Comments \\
\hline 1 & Absolute fit & $\begin{array}{l}\text { Root mean square of error } \\
\text { approximation (RMSEA) }\end{array}$ & 0.075 & $<0.08$ & The required level is achieved \\
\hline 2 & Incremental fit & Turker-lewis index (TLI) & 0.929 & $>0.90$ & The required level is achieved \\
\hline 3 & Parsimonious fit & $\begin{array}{l}\text { Chi-square/degree of } \\
\text { freedom (Chisq/df) }\end{array}$ & 3.250 & $<0.30$ & The required level is achieved \\
\hline
\end{tabular}

Source: Data analysis, 2017. freedom (Chisq/df) 
The analysis goes on with the examination of the fitness indexes. Therefore, in order to retain or reject the hypothesized model, incremental fits, absolute fits and parsimonious fits were examined. The examination of the fitness indexes as presented in Table 4 (borrowed from the study by Elias et al. (2018) indicates that the indexes values obtained meet the required level of the model fit. Therefore, we confirmed that the data fit well the model.

Table 4 shows the fitness of the measurement model, an index was archived; which guaranteed the study to go on modelling for structural equation model.

\subsection{Empirical Results}

The latent exogenous variable owner-manager entrepreneurial, managerial and functional competencies have been regressed to endogenous variable performance (changes in life style of the owner-manager as well as in the changes in number of customers purchasing from the business) in one structural model. The level of significance (p-values) was used to test the influence of each variable on performance.

\begin{tabular}{l|c|c|c|c}
\hline Table-5. Results for the effect of owner-manager competencies on the performance of small restaurant businesses. \\
\hline Construct & Coef. & Std. error. & z & P-Value \\
\hline Changes in lifestyle & & & & \\
\hline Entrepreneurial & 0.81905 & 0.782326 & 1.05 & 0.349 \\
\hline Functional & 0.13618 & 0.025435 & 5.35 & 0.001 \\
\hline Managerial & 0.59637 & 0.216348 & 2.76 & 0.006 \\
\hline Number of customers & & & & \\
\hline Entrepreneurial & 0.301590 & 0.282464 & 1.06 & 0.110 \\
\hline Functional & 1.256077 & 0.251787 & 4.99 & 0.001 \\
\hline Managerial & 1.042405 & 0.266409 & 3.91 & 0.001 \\
\hline
\end{tabular}

Source: Researcher, 2017

The result on the influence of owner-manager competencies toward the level of performance revealed a significant and positive influence on managerial and functional competencies for the number of customer and changes in lifestyle as reflected on Table 5. Additionally, entrepreneurial competencies we're not found to influence both performance measures as indicated in Table 5 results. The P-value is $>0.05$ to mean that entrepreneurial competencies are not a determinant of small restaurants business performance.

\section{Discussion}

The aim of this study was to determine the influence of owner-manager competencies on performance of small restaurant businesses in urban Tanzania. Contrary to theory and other studies, this study did not find a significant relationship between entrepreneurial competencies and performance of small restaurant businesses. Some authors have speculated that, in most cases the entrepreneurial competencies are used at the initial stage of the business, where the owner-manager needs to establish the business. The reason behind is, the routine attainment or change in the provision of service to customers involves additional costs in which it can raise price of the food offered, thus can decrease customers because customers are sensitive to price. These findings are in line with the studies by Sarwoko et al. (2013); Ahmad et al. (2010) and Man et al. (2002).

The current study shows that, owner-manager managerial competencies influence performance of small restaurant business in terms of number of customers as well as changes in lifestyle of the owner-manager as results of the business. This is because most of these businesses employ unskilled labor therefore, motivating, leading them is very important for the performance of the business. These findings are in line with, Mothibi (2015) and Chandler and Hanks (1994).

Our result also supports that there is positive and significant relationship on the influence of owner-manager functional competencies and performance in small restaurant businesses in both measures. Therefore, the ability of the owner-manager to use modern processing facilities helps in increasing speed of offering services and especially at picks times hence customer satisfaction. Furthermore, the ability of the owner-manager to deliver services to customers' locations increases customers as most of them save time while saved within their offices. Likewise, the ability to design an attractive business environment offers the possibilities of customers to be attracted to dine within the restaurant. These findings are in line with Chu et al. (2005); Chu and Benzing (2009) and Mohamad and Sidek (2013).

It was also observed that male owner-managers have more ability to apply managerial and functional skills in relation to the performance of commercial enterprise than their female counterparts. This implies that restaurant owned by males has higher chances of performing better than those owned by females. The explanation behind this observation is that male owner-managers have been found to have higher motives in business than females because they equip themselves to attain more of the competencies to perform.

\section{Conclusion and Policy Implications}

Based on empirical findings, we conclude that, managerial and functional competencies are important predictors of small restaurant businesses performance in terms of changes in lifestyle of the owner-manager and changes in number of customers within the businesses. Also male owner-managers apply competencies for business performance more than female owner-managers. This has also been highlighted by the study by Elias et al. (2018) that majority of female owner-managers are found in micro-scale due to multi responsibility they have in the family. Dividing their time to manage the business as well as the family matters reduces the effort to gain and use competencies for performance. The findings imply that, special training can be designed for female's ownermanagers to enable them to separate business and family responsibilities. The policy also can consider providing incentives for the new established firm to ensure growth in gaining experience for more major competencies toward performance. One of the more insignificant and surprising findings to emerge from this study is that an entrepreneurial competency is not the determinant of small restaurant business performance in terms of both 
changing in lifestyle and the number of customers. Given the importance of entrepreneurial competencies into the performance of the business, it can therefore be assumed that, entrepreneurial competencies set operational needs on which managerial and functional competencies are attached to ensure the performance. This is because, entrepreneurial competencies are static in nature, and it explores the prevailing business opportunities at first. It is therefore implies that, performance relies on base/platform (entrepreneurial) and operational (managerial and functional) that need to be improved. As such, policy makers may not only base on entrepreneurial aspects but also extend to the managerial and functional aspects of performance. Theoretically, it implies that, unless entrepreneurial competencies can be measured in other size, nature, sector and competition of the business, then we can know if they can improve performance. Thus, human capital theory can advance in showing that, different businesses need different skills and knowledge for their improved performance.

\section{References}

Ahmad, N.H., H.A. Halim and S.R.M. Zainal, 2010. Is entrepreneurial competency the silver bullet for SME success in a developing nation. International Business Management, 4(2): 67-75.Available at: https://doi.org/10.3923/ibm.2010.67.75.

Ahmad, N.H., T. Ramayah, C. Wilson and L. Kummerow, 2011. Is entrepreneurial competency and business success relationship contingent upon business environment? A Study of Malaysian SMES. International Journal of Entrepreneurial Behavior and Research, 16(3): 182-203.Available at: https://doi.org/10.1108/13552551011042780.

Anyim, C.F., O.C. Chidi and A.E. Badejo, 2012. Motivation and employees performance in the public and private sectors in Nigeria. International Journal of Business Administration, 3(1): 31-40.Available at: https://doi.org/10.5430/ijba.v3n1p31.

Becker, G., 1964. Human capital. New York: GS Becker.

Bird, B., 1995. Towards a theory of entrepreneurial competency: Advances in entrepreneurship. Firm Emergence and Growth, 2(1): 51-72.

Chandler, G.N. and S.H. Hanks, 1994. Founder competence, the environment, and venture performance. Entrepreneurship Theory and Practice, 18(3): 77-89.Available at: https://doi.org/10.1177/104225879401800306.

Chen, H.-S. and T. Hsieh, 2011. The effect of atmosphere on customer perceptions and customer behavior responses in Chain Store Supermarkets. African Journal of Business Management, 5(24): 10054-10066.Available at: https://doi.org/10.5897/ajbm 10.608.

Chu, H.M. and C. Benzing, 2009. A comparison of the motivations of small business Owners in Africa. Journal of Small Business and Enterprise Development, 16(1): 60-77.Available at: https://doi.org/10.1108/14626000910932881.

Chu, H.M., C. Benzing and R. Bove, 2005. The motivation, problems and perceived success of entrepreneurs in Romania. Journal of the Academy of Business Administration, 10(1-2): 73-88.

Dirisu, J.I., O. Iyiola and O. Ibidunni, 2013. Product differentiation: A tool of competitive advantage and optimal organizational performance (a study of unilever nigeria plc). European Scientific Journal, 9(34): 258-281.

Eddie, S., 2002. Don't be afraid to delegate. Department of Public Administration and Development Studies, University of South Africa, 21(2): 66-79.

Elias, R., M. Leonard and J. Mwakujonga, 2018. Determinants of owner-manager competencies for small business bperations: Evidence from a Small Restaurant Business in Tanzania. Asian Business Research Journal, 3(1): 41-47.

Fatoki, O., 2013. The determinants of longevity of micro enterprises in South Africa. Journal of Economics, 4(2): 133-143.Available at: https://doi.org/10.1080/09765239.2013.11884973.

Frazer, L., 2012. The effect of internal control on the operating activities of small restaurants. Journal of Business \& Economics Research, 10(6): 361-374.Available at: https://doi.org/10.1016/j.ijhm.2016.10.002.

Gagić, S., D. Tešanović and A. Jovičić, 2013. The vital components of restaurant quality that affect guest satisfaction. Turizam, 17(4): 166176.Available at: https://doi.org/10.5937/turizam1304166g.

Gursoy, D. and N. Swanger, 2007. Performance-enhancing internal strategic factors: Impacts on financial success. International Journal of Hospitality Management, 26(1): 213-227.Available at: https://doi.org/10.1016/j.ijhm.2006.01.004.

Hair, J.F., W.C. Black, B.J. Babin and R.L. Tatham, 2006. Multivariate data analysis. New Jersey: Prentice Hill.

Jenkins, W.J., 2015. Marketing strategies for profitability in small independent restaurants. Waiden Dessertation and Doctorial Studies. Walden University.

Jogaratnam, G., 2017. The effect of market orientation, entrepreneurial orientation and human capital on positional advantage: Evidence from the restaurant industry. International Journal of Hospitality Management, 60: 104-113.Available at: https://doi.org/10.1016/j.ijhm.2016.10.002.

Kaura, V., 2012. A link for perceived price, price fairness and customer satisfaction. Pacific Business Review International Journal, 5(6): 8488.

Khan, E.A., 2010. Core competencies of micro businesses as sources of competitive advantage: An exploratory study of street food vending Asian Institute of Technology.

Koutroumanis, D.A., 2011. Technology's effect on hotels and restaurants: Building a strategic competitive advantage. Journal of Applied Business and Economics, 12(1): 72-80.

Longenecker, C.O., L.S. Jack and W.S. Thomas, 1999. Why organizations fail: The view from the front-line. Management Decision, 37(6): 503-513.Available at: https://doi.org/10.1108/00251749910278023.

Man, T.W., T. Lau and K. Chan, 2002. The competitiveness of small and medium enterprises: A conceptualization with focus on entrepreneurial competencies. Journal of Business Venturing, 17(2): 123-142.

Man, T.W.Y., 2001. Entrepreneurial competencies and the performance of small and Medium enterprises in the Hong Kong Services Sector. Hong Kong Polytechnic University.

Mandabach, K.H., M.A. Siddiqui, G.F. Blanch and D.M. VanLeeuwen, 2011. Restaurant viability: Operations rating of contribution success factor. Journal of Culinary Science of Technology, 9(2): 71-84.Available at: https://doi.org/10.1080/15428052.2011.

Masoud, E.Y., 2013. The impact of functional competencies on firm performance of pharmaceutical industry in Jordan. International Journal of Marketing Studies, 5(3): 56-72.

MIGA, T.W.B.G.I.G.A., 2002. Tourism in Tanzania: Investment for growth and diversification. Washington DC: MIGA and United Republic of Tanzania in cooperation with The Promote Africa Program.

Mohamad, M.R. and S. Sidek, 2013. The role of entrepreneurial competencies as a mediator in the relationship between microfinance and small business growth. Journal of Entrepreneurship and Business, 1(1): $21-31$.

Mothibi, G., 2015. The effects of entrepreneurial and firm characteristic on performance of small and medium enterprises in Pretoria. International Journal of Economics, Commerce and Management United Kingdom, 3(3): 1-8.

Munene, J., J.K. Ongori and M. Iravo, 2013. Factors affecting performance of hotels and restaurants in Kenya: A case of Kisii County. Interdisciplinary Journal of Contemporary Research in Business, 4(12): 897-928.

Nangale, G., 2012. The role of the state in economic development: Employment Challenges in Eastern Africa-the Case of Tanzania. Proceeding of the Friedrich Ebert Stiftung (FES) Eastern African Conference on Employment Policies in Nairobi, Kenya. Nairobi: Friedrich Ebert Stiftung.

Parsa, H., J. Self, S. Sydnor-Busso and H.J. Yoon, 2011. Why restaurants fail? Part ii-the impact of affiliation, location, and size on restaurant failures: Results from a survival analysis. Journal of Foodservice Business Research, 14(4): 360-379.Available at: https://doi.org/10.1080/15378020.2011.625824.

Sabir, R.I., O. Ghafoor, I. Hafeez, N. Akhtar and A.U. Rehman, 2014. Factors affecting customers satisfaction in restaurants industry in Pakistan. International Review of Management and Business Research, 3(2): 869-876.

Sarwoko, E., A. Surachman and H. Djumilah, 2013. Entrepreneurial characteristics and competency as determinants of business performance in SMEs. Journal of Business and Management, 7(3): 31-38. 
Sharma, A. and A. Upneja, 2005. Factors influencing financial performance of small hotels in Tanzania. International Journal of Contemporary Hospitality Management, 17(6): 504-515.Available at: https://doi.org/10.1108/09596110510612149.

Suchánek, P., J. Richter and M. Králová, 2015. Customer satisfaction, product quality and performance of companies. Review of Economic Perspectives, 14(4): 329-344.

Tendai, C., 2013. Networks and performance of small and medium enterprises (SMEs) in different stages of the life cycle: A case study of a small business in the Netherlands. Journal of Communication, 4(2): 89-94.Available at: https://doi.org/10.1080/0976691x.2013.11884811.

Tundui, C., 2012. Survival, growth strategies and performance of women Owned Micro and small businesses in Tanzania. International Journal of Business and Management, 7(8): 143-155.

U.R.T., 2003. Small and medium enterprise development policy. Dar es Salaam: Tanzania.

Zainudin, A.Z., 2015. A handbook of SEM. Universiti Sultan Zainal Abidin. MPWS Publisher.

Zulkiffli, S.N.A., 2014. Business performance for SMEs: Subjective or objective measures? Review of Integrative Business and Economics Research, 3(1): 371-381. 